\title{
PENGARUH MODEL PEMBELAJARAN ARIAS (ASSURANCE, RELEVANCE, INTEREST, ASSESSMENT, DAN SATISFACTION) TERHADAP PEMAHAMAN KONSEP MATEMATIKA SISWA KELAS VII SMP NEGERI 4 SINGARAJA
}

\author{
N. P. Rina Marjawati, I. Md. Ardana, I. G. P. Suharta \\ Jurusan Pendidikan Matematika Universitas Pendidikan Ganesha \\ Singaraja, Indonesia \\ e-mail: puturina53@yahoo.com , ardanaimade@yahoo.com , igpsuharta@yahoo.com
}

\begin{abstract}
ABSTRAK
Penelitian ini bertujuan untuk mengetahui pengaruh model pembelajaran ARIAS terhadap pemahaman konsep matematika siswa kelas VII SMP Negeri 4 Singaraja. Jenis penelitian ini adalah eksperimen semu (quasi experiment). Populasi pada penelitian ini adalah seluruh siswa kelas VII SMP Negeri 4 Singaraja tahun ajaran 2017/2018 yang terdiri dari 10 kelas dengan jumlah siswa keseluruhan sebanyak 320 orang. Pengambilan sampel dilakukan dengan teknik cluster random sampling. Melalui proses pengundian diperoleh sampel kelas VII A2 dan VII B2 sebagai kelompok eksperimen serta kelas VII B3 dan VII B4 sebagai kelompok kontrol. Rancangan eksperimen ini menggunakan post test only control group design. Data berupa skor pemahaman konsep matematika siswa diambil dengan menggunakan tes pemahaman konsep bentuk uraian. Dari hasil pengujian hipotesis dengan menggunakan teknik Uji-t satu ekor diperoleh nilai t-hitung sebesar 43,846 dengan $\mathrm{t}$-tabel ( $\mathrm{dk}=126 ; \alpha=0,05$; satu ekor) sebesar 1,98. Dengan demikian diperoleh kesimpulan bahwa pemahaman konsep matematika siswa kelas VII SMP Negeri 4 Singaraja yang mengikuti pembelajaran dengan model pembelajaran ARIAS lebih baik daripada pemahaman konsep matematika siswa kelas VII SMP Negeri 4 Singaraja yang mengikuti pembelajaran konvensional.
\end{abstract}

Kata-kata kunci: model pembelajaran ARIAS, pemahaman konsep matematika siswa, eksperimen semu

\begin{abstract}
This research was aimed at knowing the effect of ARIAS learning model on mathematics conceptual comprehension of $7^{\text {th }}$ grade students of SMP Negeri 4 Singaraja. This research was a quasi experiment and used Post Test Only Control Group Design. The population of this research was all $7^{\text {th }}$ grade students of SMP Negeri 4 Singaraja in academic year 2017/2018 which consists of 320 students which were distributed into 10 classes. The sample was taken by cluster random sampling technique and four classes were chosen as samples i.e. VII A2 and VII B2 as experimental groups and VII B3 and VII B4 as control groups. The data of students' mathematics conceptual comprehension was collected by using the test of mathematics conceptual comprehension in essay form. Hypothesis testing was used one tailed t-test, resulting the t-value $=43,846$ where the value of t-table $(d f=126 ; \alpha=0.05)$ is 1.98 . Therefore, from that result can be concluded that the mathematics conceptual comprehension of $7^{\text {th }}$ grade students of SMP Negeri 4 Singaraja who learn with ARIAS learning model by is better than the mathematics conceptual comprehension of $7^{\text {th }}$ grade students of SMP Negeri 4 Singaraja who learn with conventional learning method
\end{abstract}

Keywords: ARIAS learning model, mathematics conceptual comprehension, quasi experiment

\section{PENDAHULUAN}

Pengetahuan merupakan hal utama yang diperoleh dari pendidikan. Melalui pengetahuan kita dapat mengetahui tentang berbagai hal mulai dari matematika, sejarah, sastra untuk ilmu politik dan lain sebagainya. Pengetahuan yang diperoleh dari pendidikan memiliki peran besar dalam menjamin kehidupan suatu bangsa dan negara. Bahkan salah satu tujuan nasional bangsa Indonesia yang tercantum dalam pembukaan undang-undang dasar 1945 adalah mencerdaskan kehidupan bangsa. Selain itu, tujuan pendidikan di Indonesia juga tertuang dalam Undang-Undang Republik 
Indonesia Nomor 20 Tahun 2003 tentang Sistem Pendidikan Nasional (2003:3) menyatakan,

Pendidikan adalah usaha sadar dan
terencana untuk mewujudkan
suasana belajar dan proses
pembelajaran agar peserta didik
secara aktif mengembangkan
potensi dirinya untuk memiliki
kekuatan spritual keagamaan,
pengendalian diri, kepribadian,
kecerdasan, akhlak mulai serta
keterampilan yang diperlukan
dirinya, masyarakat, bangsa dan
negara.

Berdasarkan hal tersebut, pendidikan memiliki peranan penting untuk membangun sumber daya manusia yang berkualitas bagi bangsa dan negara. Kualitas dari sumber daya manusia yang ada bergantung pada kualitas mutu pendidikan itu sendiri. Jadi semakin tinggi mutu pendidikannya maka semakin tinggi pula kualitas sumber daya manusianya.

Untuk meningkatkan kualitas pendidikan di Indonesia, pemerintah telah melakukan beberapa upaya seperti (1) meningkatkan akses pemerataan pendidikan, (2) meningkatkan kualifikasi guru dan dosen melalui sertifikasi, (3) meningkatkan nilai rata-rata kelulusan dalam ujian nasional, (4) membangun infrastruktur seperti menambah jumlah komputer, laboratorium, dan perpustakaan di sekolah-sekolah, (5) meningkatkan anggaran pendidikan, dan (6) melakukan revisi kurikulum secara berkala. Kurikulum yang berlaku di Indonesia saat ini adalah Kurikulum Tingkat Satuan Pendidikan (KTSP) dan Kurikulum 2013. Prinsip Kurikulum 2013 ini secara umum hampir sama dengan KTSP, yakni pembelajaran berpusat pada siswa (student centred), guru hanya sebagai fasilitator dan motivator saja.

Rendahnya kualitas pendidikan di Indonesia tersebut dapat dilihat melalui hasil survei dari studi internasional TIMSS (Trends in International Mathematics and Science Study) yaitu studi internasional tentang prestasi matematika dan sains siswa sekolah lanjutan tingkat pertama yang dilakukan empat tahun sekali sejak tahun 1995. TIMSS menempatkan Indonesia pada peringkat ke-34 dari 38 negara tahun 1999, peringkat ke-35 dari 46 negara tahun 2003, peringkat ke-36 dari 49 negara pada tahun 2007, dan peringkat ke-38 dari 42 negara pada tahun 2011 (Sadewo, 2014). Bahkan laporan terbaru TIMSS 2015 menunjukkan Indonesia berada pada peringkat ke-44 dari 49 negara (TIMSS, 2015). Dari survei tersebut terlihat bahwa indeks prestasi belajar matematika siswa masih rendah. Salah satu penyebab rendahnya prestasi belajar matematika siswa adalah kurangnya pemahaman konsep siswa terhadap pelajaran matematika. Hal ini berkaitan dengan penelitian yang dilakukan oleh Darmiko Purnomo (2012) yang menyebutkan bahwa pemahaman konsep memiliki hubungan yang signifikan dengan prestasi belajar, dengan demikian semakin tinggi pemahaman konsep siswa, maka semakin tinggi pula prestasi belajar siswa tersebut. Padahal matematika merupakan salah satu ilmu dasar yang mempunyai peranan penting dalam penguasaan dan perkembangan ilmu pengetahuan dan teknologi (Suherman, 2003).

Seperti yang kita ketahui, matematika merupakan bidang studi yang dipelajari oleh semua siswa dari TK, SD hingga SMA bahkan sampai di Peguruan Tinggi. Ada banyak alasan tentang perlunya siswa belajar matematika, yaitu : (1) merupakan sarana berpikir yang jelas dan logis, (2) sarana memecahkan masalah sehari-hari, (3) sarana mengenal pola-pola hubungan dan generalisasi pengalaman, (4) sarana untuk mengembangkan kreativitas, dan (5) sarana untuk meningkatkan kesadaran terhadap perkembangan budaya. Kegiatan pembelajaran matematika tidak akan memberikan hasil belajar yang maksimal apabila peserta didik tidak memahami konsep dari matematika itu sendiri. Artinya dalam mempelajari matematika siswa harus memahami konsep terlebih dahulu agar dapat menyelesaikan soal-soal dan mampu mengaplikasikan konsep tersebut di dunia nyata. 
Menurut NCTM (2000), pemahaman siswa terhadap konsep matematika dapat dilihat dari kemampuan siswa dalam beberapa kriteria, yaitu (1) Menyatakan konsep dengan kata-kata sendiri; (2) Mengidentifikasi/memberi contoh dan bukan contoh dari konsep; (3) Mengaplikasikan/menggunakan konsep dengan benar dalam berbagai situasi. Dengan demikian dapat dikatakan pemahaman terhadap konsep-konsep matematika merupakan dasar untuk belajar matematika secara bermakna. Dengan kata lain, pemahaman konsep matematika adalah bekal untuk dapat mengembangkan pengetahuan tentang matematika dalam lingkup yang lebih besar terutama mengaplikasikannya pada dunia nyata maupun dunia kerja. Oleh karena itu, pemahaman konsep matematika sangat penting untuk dimiliki oleh siswa.

Berdasarkan hal di atas sudah sepantasnya pendidik harus memiliki strategi-strategi dalam mengajar konsepkonsep matematika. Hal ini sesuai dengan salah satu tujuan pembelajaran matematika menurut Depdiknas (2006) yaitu memahami konsep matematika, menjelaskan keterkaitan antar konsep dan mengaplikasikan konsep atau algoritma secara luas, akurat, efisien dan tepat dalam pemecahan masalah. Seorang pendidik haruslah mengerti situasi dan kondisi siswanya, agar saat melakukan pembelajaran dapat menggunakan strategi, metode, ataupun model yang tepat. Sehingga, guru sebagai seorang pendidik mampu melakukan pembelajaran seoptimal mungkin di dalam kelas agar materi yang disampaikannya mudah dipahami dan bermanfaat bagi siswanya.

Salah satu model pembelajaran inovatif yang dapat diterapkan dalam pembelajaran matematika untuk mengasah pemahaman konsep peserta didik adalah model pembelajaran ARIAS (Assurance, Relevance, Interest, Assessment dan Satisfaction). Model pembelajaran ARIAS merupakan model pembelajaran yang sederhana, sistematika, bermakna, dan dapat digunakan oleh para guru sebagai dasar untuk melaksanakan kegiatan pembelajaran dengan baik. Model pembelajaran ARIAS dalam pembelajaran matematika menekankan pembelajaran yang berpusat pada siswa, namun guru juga memegang peranan yang sangat penting. Kelima komponen model pembelajaran ARIAS tersebut harus dilaksanakan secara berkesinambungan dalam pembelajaran karena merupakan satu kesatuan.

Assurance merupakan komponen yang pertama pada model pembelajaran ARIAS yang menekankan pada usaha guru dalam menanamkan rasa percaya diri siswa sehingga siswa tidak akan ragu dan malu pada saat mengikuti pembelajaran. Dengan ditanamkannya sikap percaya diri, siswa akan mampu mengikuti kegiatan pembelajaran tanpa harus merasa malu ataupun tertekan dan bahkan siswa akan lebih bersemangat dalam mengikuti pembelajaran. Relevance berkaitan dengan bagaimana peran guru dalam membuat kaitan antara materi yang dipelajari dengan kehidupan sehari-hari sehingga siswa memiliki motivasi belajar dan minat belajar. Selain itu interest atau perhatian tetapi juga harus dipelihara selama kegiatan pembelajaran berlangsung. Perhatian siswa terhadap materi maupun tugas yang diberikan akan memotivasi dan mendorong siswa untuk memahami konsep dari materi yang diberikan. Untuk dapat memahami konsep matematika, assesment sangatlah diperlukan. Tujuan assessment adalah untuk mendapatkan umpan balik dari siswa sehingga siswa mengetaui sampai sejauh mana mereka menguasai konsep matematika. Keberhasilan dalam menguasai konsep matematika akan memberikan kepuasan atau satisfaction bagi siswa. Kepuasan yang diperoleh siswa akan membuat siswa lebih termotivasi untuk mengikuti kegiatan pembelajaran selanjutnya.

Melalui pembelajaran dengan menggunakan model pembelajaran ARIAS siswa lebih banyak diberikan latihan soal yang relevan dengan kehidupan seharihari, sehingga siswa akan terlatih dalam menyelesaikan masalah yang diberikan.

Beberapa penelitian menunjukan model pembelajaran ARIAS memberikan 
pengaruh yang baik terhadap berbagai kegiatan pembelajaran. Sri Margareta (2013) telah melakukan penelitian terkait hasil belajar siswa dengan menggunakan model pembelajaran ARIAS. Dalam penelitian tersebut Model Pembelajaran ARIAS lebih baik dalam meningkatkan hasil belajar siswa daripada dengan pembelajaran konvensional. Berdasarkan penelitian tersebut tampak bahwa model pembelajaran ARIAS memberikan pengaruh positif terhadap hasil belajar siswa. Murniawati dkk (2015) dalam penelitiannnya menyebutkan bahwa pemahaman konsep memiliki hubungan yang positif dengan hasil belajar. Hal ini berarti jika hasil belajar siswa baik, maka pemahaman konsep siswa juga baik.

Berdasarkan uraian di atas, model pembelajaran ARIAS memiliki peluang untuk meningkatkan pemahaman konsep matematika siswa. Untuk mengetahui kebenaran tersebut, perlu dilakukan penelitian dengan melakukan eksperimen terhadap penerapan model pembelajaran ARIAS dalam meningkatkan pemahaman konsep matematika. Karena sepanjang pengetahuan peneliti, belum ada hasil penelitian yang menunjukan model pembelajaran ARIAS meningkatkan pemahaman konsep matematika.

Oleh karena itu, peneliti tertarik melakukan penelitian tentang pengaruh model pembelajaran ARIAS terhadap pemahaman konsep matematika siswa, terutama siswa kelas VII yang berjudul "Pengaruh Model Pembelajaran ARIAS (Assurance, Relevance, Interest, Assessment dan Satisfaction) Terhadap Pemahaman Konsep Matematika Siswa Kelas VII SMP Negeri 4 Singaraja"

\section{METODE}

Jenis penelitian dalam penelitian ini adalah penelitian eksperimen semu. Penelitian ini bertujuan untuk menguji variabel bebas terhadap variabel terikat. Penelitian ini bertujuan untuk mengetahui pengaruh model pembelajaran ARIAS terhadap pemahaman konsep matematika siswa kelas VII SMP Negeri 4 Singaraja.
Populasi dalam penelitian ini adalah seluruh siswa kelas VII SMP Negeri 4 Singaraja tahun ajaran 2017/2018. Banyaknya anggota populasi dalam penelitian ini adalah 320 orang siswa. Pengambilan sampel dilakukan dengan teknik cluster random sampling dari populasi yang sudah diuji kesetaraannya dengan ANAVA satu jalur sehingga akan ada empat sampel yang akan diundi lagi untuk menentukan satu kelas kontrol dan satu kelas eksperimen. Dari pengundian tersebut diperoleh kelas VII A2, VII B2, VII B3 dan VII B4. Dari keempat kelas yang terpilih secara random tersebut akan diundi kembali untuk menentukan kelas eksperimen dan kelas kontrol. Berdasarkan hasil pengundian, terpilih kelas VII A2 dan VII B2 sebagai kelas eksperimen dan VII B3 kelas VII B4 sebagai kelas kontrol.

Data pada penelitian ini adalah pemahaman konsep matematika siswa yang dikumpulkan melalui tes yang berbentuk uraian. Setelah kelompok sampel diberi perlakuan, dilakukan pengujian terhadap hipotesis yang diajukan. Terlebih dahulu, data yang diperoleh dilakukan pengujian normalitas sebaran data dengan Uji Liliefors dan pengujian homogenitas varians dengan uji $F$. Selanjutnya pengujian hipotesis dilakukan dengan uji-t untuk mengetahui apakah pemahaman konsep matematika siswa kelas VII SMP Negeri 4 Singaraja yang mengikuti model pembelajaran ARIAS (Assurance, Relevance, Interest, Assessment dan Satisfaction) lebih tinggi daripada pemahaman konsep matematika yang mengikuti pembelajaran konvensional.

\section{HASIL DAN PEMBAHASAN}

Data pada penelitian ini adalah skor pemahaman konsep matematika siswa yang diperoleh melalui kegiatan post-test dengan menggunakan instrumen yang sebelumnya telah disusun dan telah melalui tahap uji validitas dan reliabilitas. Rangkuman statistik deskriptif data pada kelompok eksperimen dan kelompok kontrol disajikan pada Tabel 1. 
Tabel 1. Rangkuman Statistik Deskriptif Data Kelompok Eksperimen dan Kelompok Kontrol

\begin{tabular}{lcc}
\hline \multicolumn{1}{c}{ Variabel } & Kelompok Eksperimen $\left(\mathbf{Y}_{\mathbf{1}}\right)$ & Kelompok Kontrol $\left(\mathbf{Y}_{\mathbf{2}}\right)$ \\
\hline$\sum Y_{i}$ & 1640 & 1229 \\
$\boldsymbol{n}_{\boldsymbol{i}}$ & 64 & 64 \\
Mean $\left(\overline{Y_{i}}\right)$ & 25,625 & 19,203 \\
Median $(\boldsymbol{M})$ & 27 & 20 \\
Modus $(\boldsymbol{M o})$ & 27 & 20 \\
Maks & 36 & 32 \\
Min & 11 & 8 \\
Range $(\boldsymbol{r})$ & 25 & 24 \\
$\boldsymbol{s}_{i}{ }^{2}$ & 37,508 & 26,625 \\
$\boldsymbol{S D}_{\boldsymbol{i}}$ & 6,124 & 5,443 \\
\hline
\end{tabular}

Analisis data untuk menguji hipotesis dilakukan dengan menggunakan Uji-t satu ekor. Sebelum Uji-t dilakukan, terlebih dahulu dilakukan uji normalitas dan homogenitas data sebagai prasyarat normalitas dan homogenitas dalam melakukan Uji-t.

Perhitungan uji normalitas data pemahaman konsep matematika siswa pada kelompok eksperimen dan kelompok kontrol dilakukan dengan menggunakan Uji Lilliefors. Data dikatakan berasal dari populasi yang berdistribusi normal apabila nilai $L$-hitung $<$ nilai $L$-tabel $(n ; \alpha=0,05)$. Hasil perhitungan uji normalitas dengan Uji Lilliefors tersebut diperoleh nilai L-hitung untuk kelompok eksperimen sebesar 0,094 dengan nilai $L$-tabel ( $n=64 ; \alpha=0,05$ ) sebesar 0,110 dan nilai $L$-hitung untuk kelompok kontrol sebesar 0,101 dengan nilai $L$-tabel $(n=64 ; \alpha=0,05)$ sebesar 0,110 . Ini berarti bahwa nilai $L$-hitung baik dari kelompok eksperimen maupun kelompok kontrol sama - sama kurang dari nilai $L$-tabel, hal tersebut menunjukkan bahwa data baik dari kelompok eksperimen maupun kelompok kontrol berasal dari populasi yang berdistribusi normal.

Selanjutnya, pengujian homogenitas data dilakukan dengan menggunakan Uji Levene. Data dikatakan memiliki varian yang homogen jika nilai $W<$ nilai $F$-tabel. Dari perhitungan homogenitas data diperoleh nilai $W$ sebesar 1,207 dengan nilai $F$-tabel ( $d k$ pembilang $=1 ; d k$ penyebut $=126 ; \alpha=0,05)$ sebesar 3,920. Jika dibandingkan, maka nilai $W<$ nilai $F$-tabel, sehingga dapat disimpulkan bahwa data pada kedua kelompok memiliki varian yang homogen.

Setelah data pada kelompok eksperimen dan kelompok kontrol dinyatakan normal dan homogen, maka pengujian hipotesis dengan menggunakan teknik Uji- $t$ satu ekor dapat dilakukan. Pada teknik Uji-t satu ekor, $\mathrm{H}_{0}$ ditolak jika nilai $t$ hitung $>$ nilai $t$-tabel $\left(d k=n_{1}+n_{2}-2 ; \alpha=\right.$ $0,05)$ satu ekor. Dari hasil analisis data dengan menggunakan perhitungan Uji-t diperoleh nilai $t$-hitung sebesar 43,846 dengan nilai $t$-tabel $(d k=126 ; \alpha=0,05)$ satu ekor sebesar 1,98. Jika dibandingkan, maka nilai $t$-hitung > nilai $t$-tabel. Dengan demikian dapat disimpulkan bahwa pemahaman konsep matematika siswa kelas VII SMP Negeri 4 Singaraja yang mengikuti pembelajaran dengan model pembelajaran ARIAS lebih baik daripada pemahaman konsep matematika siswa kelas VII SMP Negeri 4 Singaraja yang mengikuti pembelajaran konvensional.

\section{Pembahasan}

Berdasarkan hasil pengujian hipotesis yang telah dilakukan dengan membandingkan pemahaman konsep matematika kelompok eksperimen dengan kelompok kontrol melalui perhitungan Uji-t 
satu ekor diperoleh bahwa pemahaman konsep matematika siswa pada kelompok eksperimen lebih tinggi dari pada pemahaman konsep matematika siswa pada kelompok kontrol. Hal tersebut berarti bahwa penerapan model pembelajaran ARIAS memberikan pengaruh yang berarti terhadap pemahaman konsep matematika siswa.

Hasil pada uji hipotesis tersebut dapat terjadi karena pada kegiatan pembelajaran dengan model pembelajaran ARIAS yang diterapkan di kelompok eksperimen mampu membuat siswa memiliki sikap percaya diri, bersemangat dan memperhatikan guru dalam kegiatan pembelajaran. Penyampaian materi yang dikaitkan dengan kehidupan sehari-hari membuat siswa bersemangat untuk mengikuti kegiatan pembelajaran. Pada saat guru menyampaikan materi, siswa dituntut untuk selalu memperhatikan agar penguasaan materi siswa meningkat. Dengan demikian, pemahaman konsep siswa akan meningkat pula. Hal tersebut sesuai dengan pendapat Rahman \& Amri (2014:56) menyatakan, "pentingnya bagi guru untuk menanamkan rasa percaya diri ini pada siswa guna mendorong dan memotivasi diri mereka untuk berhasil dan berprestasi secara optimal sehingga mampu bersaing dengan teman-temannya dalam pembelajaran".

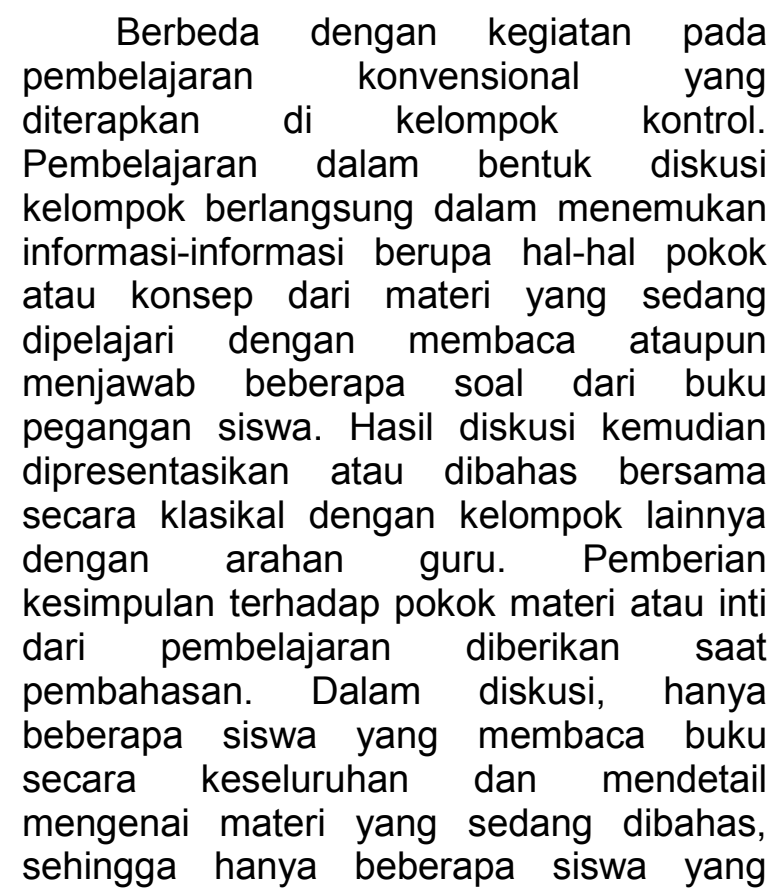

benar- benar memahami penemuan konsep-konsep terhadap materi tersebut. Sementara itu, sebagian siswa lainnya membaca hanya di bagian-bagian yang menjadi garis bawah atau pokok materi sehingga kurang memahami konsep dari materi tersebut. Hal tersebut membuat siswa kurang aktif untuk mengoptimalkan kemampuan berpikirnya dalam mengonstruksi maupun menghubungkan pengetahuan-pengetahuannya. Begitu juga ketika mengerjakan soal latihan yang ditugaskan, hanya beberapa siswa yang terlibat dalam mengerjakan soal tersebut, selebihnya ada yang mencatat ketika soal tersebut telah dibahas di depan kelas oleh siswa yang ditunjuk. Hal tersebut juga membuat daya berpikir siswa kurang aktif dan tidak terlalu optimal dalam mengonstruksi dan menerapkan pengetahuan yang dimiliki untuk memecahkan suatu permasalahan yang diberikan.

Kegiatan pembelajaran dengan model pembelajaran ARIAS mendukung siswa dalam mengembangkan pemahaman konsep matematikanya. Kelima tahap dalam model pembelajaran ARIAS yaitu Assurance, Relevance, Interest, Assesment, dan Satisfaction harus dilaksanakan secara berkesinambungan dalam pembelajaran karena merupakan satu kesatuan. Dalam model pembelajaran ARIAS, tahap assurance, relevance, dan interest mampu membuat siswa memiliki sikap percaya diri, bersemangat, dan memperhatikan guru pada saat proses pembelajaran Matematika. Dalam penelitian Renny Widyawati (2016) juga menyatakan bahwa dengan diterapkannya model pembelajaran ARIAS di kelas akan dapat mendorong tumbuhnya rasa senang siswa terhadap pelajaran, menumbuhkan dan meningkatkan motivasi dalam mengerjakan tugas, memberikan kemudahan bagi siswa mencapai hasil yang lebih baik. Pada kegiatan diskusi model pembelajaran ARIAS mampu membuat siswa berpartisipasi aktif dalam mengajukan pendapat, bekerjasama, dan membenahi konsep yang keliru pada saat mengerjakan LKS yang diberikan oleh guru. Siswa dapat mengkonstruksikan konsep 
secara bermakna dengan mengerjakan LKS kemudian mempresentasikannya. Dengan demikian pemahaman konsep siswa menjadi lebih baik. Model pembelajaran ARIAS juga dapat menumbuhkan rasa bangga pada diri siswa dengan cara memberikan penghargaan ataupun pujian setelah siswa selesai mempresentasikan hasil diskusinya. Melalui setiap kegiatan pembelajaran siswa dilatih untuk mengonstruksi pengetahuannya sendiri yang kemudian digunakan untuk menemukan, menggali dan mengkonstruksi suatu konsep. Proses inilah yang dapat meningkatkan pemahaman konsep matematika siswa. Hal tersebut menunjukkan bahwa pemahaman konsep matematika siswa dapat ditingkatkan melalui penerapan model pembelajaran ARIAS.

Hasil penelitian ini memberikan implikasi bahwa model pembelajaran ARIAS dapat diterapkan dalam pembelajaran matematika untuk pemahaman konsep matematika siswa. Berdasarkan pengaruh penerapan model pembelajaran ARIAS yang memberikan hasil positif terhadap peningkatan pemahaman konsep matematika siswa, maka pembelajaran ini dapat dikembangkan dan diterapkan dalam kegiatan pembelajaran matematika.

\section{SIMPULAN DAN SARAN}

Berdasarkan hasil pengujian hipotesis yang menggunakan uji-t pada taraf signifikansi 0,05 dapat ditarik kesimpulan bahwa pemahaman konsep matematika siswa yang mengikuti pembelajaran dengan model pembelajaran ARIAS lebih baik daripada pemahaman konsep matematika siswa yang mengikuti pembelajaran konvensional.

Kepada guru, disarankan untuk
mencoba model
pembelajaran ARIAS sebagai salah satu
alternatif pembelajaran yang kreatif dan
inovatif di kelas terutama dalam
menghadapi kurikulum 2013. Dalam
menerapkan pembelajaran dengan model
pembelajaran ARIAS pada pembelajaran

supaya memperhatikan kendala-kendala yang dihadapi dalam penelitian supaya kendala-kendala tersebut dapat diminimalisir. Penelitian ini dilakukan dengan berbagai keterbatasan, terutama dari sampel dan materi yang digunakan. Disarankan untuk peneliti yang tertarik dapat melakukan penelitian dengan model pembelajaran ARIAS untuk aspek pembelajaran yang berbeda dan pada jenjang yang berbeda. Misalnya terhadap kemampuan pemecahan masalah matematika siswa pada kelas X SMA.

\section{DAFTAR PUSTAKA}

Depdiknas. 2006. Peraturan Pemerintah RI No 22 Tahun 2006 tentang Standar Nasional Pendidikan. Jakarta: Cemerlang

Margareta,TS .2013. Pengaruh Model Pembelajaran Arias Terhadap Hasil Belajar Siswa Pada Topik Bentuk Aljabar.Skripsi. Universitas Negeri Gorontalo.

Murniawati, Ni Wayan Sri dkk. 2015. Hubungan Pemahaman Konsep Dan Motivasi Belajar Dengan Hasil Belajar Siswa (suatu penelitian yang dilaksanakan di SMP Negeri 1 Suwawa Kelas VIII). Skripsi, Program Studi Pendidikan Fisika, Jurusan Fisika, Fakultas IImu Matematika dan IImu pengetahuan Alam, Universitas Negeri Gorontalo.

NCTM. 2000. Principles and Standarts For School Mathematics. America: United States of America1.

Purnomo, Darmiko. 2012. Hubungan Antara Pemahaman Materi, Motivasi Belajar, Dan Prestasi Belajar Pada Siswa Kelas VIII SMP Taman Dewasa Ibu Pawiyatan Yogyakarta.

Rahman \& Amri. 2014. Model Pembelajaran ARIAS Terintegratif dalam Teori dan Praktik untuk Menunjang Penerapan Kurikulum 2013.Jakarta: PT. Prestasi Karya. 
Jurnal Pendidikan Matematika Undiksha, Volume IX No 2, Agustus 2018 e-ISNN:2599-2600; p-ISNN: 2613-9677

Renny Widyawati. 2016. Pengaruh Model Pembelajaran ARIAS terhadap Motivasi dan Hasil Belajar Matematika Siswa pada Materi Persamaan Garis Lurus Kelas VIII SMP Negeri 8 Kota Kediri Tahun Ajaran 2015/2016. Terdapat pada http: //simki.unpkediri.ac.id/mahasiswa /file_artikel/2016/11.1.01.05.0169.pd $\mathrm{f}$ (diakses pada 8 Februari 2018)

Suherman, E. dkk. 2003. Strategi Pembelajaran Matematika Kontemporer (Common Textbook Edisi Revisi). Bandung: Universitas Pendidikan Indonesia. 